\title{
SCHISTOSOMA MANSONI: IMMUNODEPRESSION OF HEPATIC SCHISTOSOME GRANULOMA FORMATION IN MICE INFECTED BY TRYPANOSOMA CRUZI*
}

\section{O. Genaro', Z. Brener² and P.M.Z. Coelho ${ }^{3}$}

Infection by Trypanosoma cruzi in mice depresses hepatic granuloma formation around Schistosoma mansoni eggs. This immunodepressive effect occurred in mice with Chagas' disease at the acute and/or chronic phases, granulomas being significantly smaller than those in controls. Data suggest that Chagas' disease depresses the delayed hypersensitivity immune response directly. cruzi.

Key words: Schistosoma mansoni. Immunodepression. Granuloma. Trypanosoma

Immunodepression during infection by Trypanosoma cruzi was first described by Clinton et al. ${ }^{5}$, who noted a reduction of early response of antibodies to donkey red blood cells in infected mice. Later, depression of immune response to different antigens in mice infected by $T$. cruzi 1718 and in $\operatorname{men}^{22}$ was demonstrated. The mechanisms of this immune depression in Chagas' disease have been studied by a number of authors ${ }^{6} 821$. Macknika and Choromanski ${ }^{14}$ showed that $T$. cruzi induces nonespecific immunodepression in mice reducing humoral and cellular response to antigens of Hymenolepis diminuta. A marked depression of humoral and cellular response coincidently with the peak of parasitemia occurs during the acute phase of infection by $T$. cruzi ${ }^{7}$.

In the present study we studied the effect of infection by $T$. cruzi (acute and chronic phases) on granuloma formation in mice with concomitant infection by Schistosoma mansoni.

\section{MATERIAL AND METHODS}

Swiss albino mice weighing 18-20 g were used. $S$. mansoni cercariae (LE strain, coming from Belo Horizonte, Brazil) were obtained from Biomphalaria glabrata $^{13} 16$. Mice were inoculated with about 40 cercariae subcutaneously. Three strains of $T$. cruzi were used: $Y$ strain ${ }^{20}, \mathrm{CL}$ strain $^{4}$, and Colombian

* This study was supported by CNPq and FINEP, Brazil.

1. Departamento de Patologia Tropical/INPA, Manaus

2. Centro de Pesquisas René Rachou, FIOCRUZ, Belo Horizonte

3. Departamento de Parasitologia, ICB/UFMG, Belo Horizonte

Address for reprints: Profo Paulo Marcos Z. Coelho Departamento de Parasitologia, ICB/UFMG, Caixa Postal 2486, 30000 Belo Horizonte, MG.

Recebido para publicação em $26 / 6 / 85$ strain ${ }^{12}$. Induction of the chronic phase in $\mathrm{CL}$ and Colombian strains was performed according to Brener and Chiari ${ }^{3}$. An inoculum of about $1 \times 10^{4}$ blood trypomastigotes, given by the intraperitoneal route, was the standard challenge. Using these methods, granuloma formation was studied in two groups of mice: a) infected by both $S$. mansoni and T. cruzi; b) infected by $S$. mansoni only. Control groups of uninfected animals and those only infected with $T$. cruz $i$ were maintained concurrently.

In experiment $I$, designed to study the effect of acute phase of Chagas' disease on schistosome granuloma formation, 20 mice were inoculated with $S$. mansoni. On the $43^{\text {rd }}$ day after infection, 10 out of those 20 mice, plus 10 normal ones, were inoculated with $T$. cruzi (Y strain). Since this strain is highly virulent, with a high mortality rate after the peak of parasitemia, this experiment was of short duration.

In experiments II and III, mice chronically infected by $T$. cruzi (CL and Colombian strains), and their respective controls, were distributed in 4 different groups. At 98 and 185-day-intervals after infection by $T$. cruzi animals from groups $\mathrm{A}$ and $\mathrm{C}$ were infected by S. mansoni.

At the end of each experiment, surviving mice were killed and necropsy performed. Snips from the liver of infected mice were fixed in $10 \%$ formolsaline, embedded in parafin, sliced into sections of $5 \mu \mathrm{m}$ thickness (with a $500 \mu \mathrm{m}$ interval), and stained with Hematoxilin-Eosin. The size of each granuloma was determined by the measure of two diameters intersecting at right angle, by means of an ocular micrometer.

\section{RESULTS}

Table 1 shows the mean diameter of schistosome granulomas in the liver of mice from group A $(S$. mansoni + T. cruz $i$ and group C ( $S$. mansoni only) in 
Genaro O, Brener Z, Coelho PMZ. Schistosoma mansoni immunodepression of hepatic schistosome granuloma formation in mice infected by Trypanosoma cruzi Revista da Sociedade Brasileira de Medicina Tropical 19: 35-37, Jan-Mar, 1986

Table 1 -Diameter of hepatic granulomas in mice with concomitant infection by Trypanosoma cruzi and Schistosoma mansoni

\begin{tabular}{|c|c|c|c|c|c|c|c|c|}
\hline \multirow{2}{*}{$\begin{array}{l}\text { Phase of } \\
\text { infection } \\
\text { by } \\
\text { T. cruzi }\end{array}$} & \multirow[b]{2}{*}{ Strain } & \multirow{2}{*}{$\begin{array}{c}\text { Interval } \\
\text { between } \\
\text { infections } \\
\text { (days) }\end{array}$} & \multirow{2}{*}{ 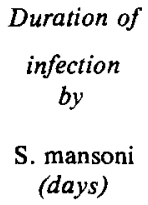 } & \multirow{2}{*}{ 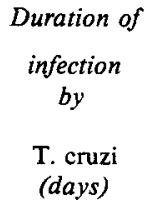 } & \multicolumn{2}{|c|}{ Mean diameter of granulomas $(, \mu m)^{*}$} & \multirow{2}{*}{$\begin{array}{l}\% \text { reduction } \\
\text { of } \\
\text { granulomas } \\
\text { in } \\
\text { size }\end{array}$} & \multirow[b]{2}{*}{$\begin{array}{c}\text { Student's } \\
\text { t test }\end{array}$} \\
\hline & & & & & $\begin{array}{c}\text { Group } A \\
\text { T. cruzi+S. mansoni }\end{array}$ & $\begin{array}{l}\text { Group B } \\
\text { S. mansoni } \\
\text { only }\end{array}$ & & \\
\hline I acute & $\mathbf{Y}$ & 43 & 54 & 11 & $164.5 \pm 5.3$ & $324.5 \pm 4.5$ & 49.3 & $\mathrm{P}<0.001$ \\
\hline Il chronic & $\mathrm{CL}$ & 68 & 62 & 130 & $195.7 \pm 5.9$ & $368.8 \pm 11.1$ & 46.9 & $P<0.00$ \\
\hline III chronic & Colombian & 185 & 135 & 320 & $192.5 \pm 15.6$ & $305.9 \pm 49.0$ & 37.0 & $\mathrm{P}<0.01$ \\
\hline
\end{tabular}

* Mean diameter of granulomas of five mice (measured 40 granulomas per animal)

the three experiments. As can be seen, the diameters of granulomas in $T$. cruzi infected animals are significantly smaller than those in controls, with a reduction rate varying from 37 to $49.3 \%$ from the normal size of granulomas in control group.

\section{DISCUSSION}

Granulomatous reactivity around $S$. mansoni eggs has been demonstrated to be a form of delayed cell-mediated hypersensitivity ${ }^{24}$. These authors showed that this kind of hypersensitivity could be transferable to non-infected mice with lymphnode cells or the spleen of immune animals, but not with serum. This hypothesis was reinforced by suppression of schistosome granuloma formation in mice, using effective techniques against delayed cell-mediated reaction, such as immunodepressive drugs ${ }^{11}$, neonatal thymectomy ${ }^{9}$, heterologous antilymphocytic serum 10 moderate or severe disease like Hodgkins ${ }^{23}$, and antimacrophage serum ${ }^{2}$. Abdel-Wahab et al. ${ }^{1}$ first demonstrated that parasitic infections such as Plasmodium yoelii had direct influence on granulomatous reactivity around $S$. mansoni eggs reducing the size of granulomas. Later, Mahmoud et al. ${ }^{15}$ verified that infection by Toxoplasma gondii also induced a marked reduction of schistosome granuloma in size.

In the present investigation, infection by $T$. cruzi produced an intense effect on schistosome granuloma size. Depression of the delayed hypersensitivity immune response was showed by reduction of hepatic granulomas in size occurring in mice infected by $T$. cruzi (Y strain) at the acute phase. This finding agrees with those of Rowland \& Kuhn ${ }^{19}$ and Costa ${ }^{7}$, who verified depression of cellular response by $T$. cruz $i$ at the acute phase of infection. Further, it shows that such immunodepression also appears in Chagas' disease during the chronic phase, as observed with $\mathrm{CL}$ and Colombian strains of $T$. cruzi.

\section{RESUMO}

A infecção de camundongos pelo Trypanosoma cruzi inibe a formação do granuloma hepático esquistossomótico. Este efeito imunodepressor ocorreu em camundongos com a fase aguda ou crônica da doença de Chagas, sendo os granulomas significativamente menores que nos animais controles. Os dados sugerem que a doença de Chagas deprime diretamente a imunidade celular.

Palavras chaves: Schistosoma mansoni. Imunodepressão. Granuloma. Trypanosoma cruzi.

\section{REFERENCES}

1. Abdel-Wahab MF, Powers KG, Mahmoud SS, Good WC. Suppression of schistosome granuloma formation by malaria in mice. American Journal of Tropical Medicine and Hygiene 23:915-918, 1974.

2. Boros DL, Warren KS. Effect of anti-macrophage serum on hypersensitivity (Schistosoma mansoni eggs) and foreign body (Divinylbenzene copoliner bead) granuloma. Journal of Immunology 107:534-539, 1971.

3. Brener Z, Chiari E. Observações sobre a fase crônica da doença de Chagas experimental no camundongo. Revista do Instituto de Medicina Tropical de São Paulo 5: 128$132,1963$.

4. Brener Z, Chiari E. Variações morfológicas observadas em diferentes amostras de Trypanosoma cruzi. Revista do Instituto de Medicina Tropical de São Paulo 5: 220224, 1963.

5. Clinton BA, Ortiz-Ortiz L, Garcia W, Martinez T, Capin R. Trypanosoma cruzi: Early immune responses in infected mice. Experimental Parasitology 37: 417 425, 1975.

6. Corsini AC, Costa MG. Immunosuppression in mice infected with Trypanosoma cruzi (Chagas, 1909). I. Evidence of polyclonal B cell activation in experimental infections mimiced by an extract prepared from circulating trypomastigotes. Revista do Instituto de Medicina Tropical de São Paulo 23:114-121, 1981. 
Genaro O, Brener Z, Coelho PMZ. Schistosoma mansoni- immunodepression of hepatic schistosome granuloma formation in mice infected by Trypanosoma cruzi Revista da Sociedade Brasileira de Medicina Tropical 19: 35-37, Jan-Mar, 1986

7. Costa MC. Imunossupressão na infecção pelo Trypanosoma cruzi (Chagas, 1909): I. Efeitos dos extratos de epimastigotas e tripomastigotas sobre a resposta imune em camundongos. Tese de Doutorado. Unicamp. Campinas. 1982.

8. Cunningham DS, Benavides GR, Kuhn RE. Suppression of mitogen-induced blastogenesis by the Trypanosoma cruzi-induced suppressor substance. The Journal of Parasitology 66: 722-729, 1980.

9. Domingo EO, Warren KS. The inhibition of granuloma formation around Schistosoma mansoni eggs. II. Thymectomy. The American Journal of Pathology 51: 757 767,1967

10. Domingo EO, Warren KS. The inhibition of granuloma formation around Schistosoma mansoni eggs. III. Heterologous antilymphocyte serum. The American Journal of Pathology 52: 613-631, 1968.

11. Domingo EO, Cowan RBT, Warren KS. The inhibition of granuloma formation around Schistosoma mansoni eggs. I. Immunosuppressive drugs. The American Journal of Tropical Medicine and Hygiene 16: 284-292, 1967.

12. Federici EE, Albermann WB, Neva FA. Chronic and progressive myocarditis and myositis in $\mathrm{C}_{3} \mathrm{H}$ mice infected with Trypanosoma cruzi. The American Journal of Tropical Medicine and Hygiene 13: 273-280, 1964.

13. Freitas JR. Ritmo de crescimento de Biomphalaria glabrata (Say, 1818). Padronização da técnica de criaçào. Tese de doutorado. Universidade Federal de Minas Gerais, Belo Horizonte, 1973.

14. Machnicka B, Choromawski L. The influence of immunosuppression generated by Trypanosoma cruzi on the development of $\mathrm{Hym}_{\mathrm{i}}$ nolepis diminuta in CFW mice. Bulletin de l'Academie Polonaise de Science. 17: 739. 748. 1979.

15. Mahmoud AAF, Strickland GT, Warren KS. Toxoplasmosis and the host-parasite relationship in murine schistosomiasis mansoni. Journal of Infectious Diseases 135:408-413, 1977

16. Pellegrino J, Katz N. Experimental chemotherapy of schistosomiasis mansoni. In: Dawes B (ed) Advances in Parasitology, Academic Press, London, p. 233-290, 1968.

17. Ramos C, Lamoyi E, Feoli M, Rodrigues M, Perez M, Ortiz-Ortiz L. Trypanosoma cruzi: immunosuppressed response to different antigens in the infected mouse. Experimental Parasitology 45: 19-199, 1978.

18. Reed SE. Larson CL. Speer CA. Suppression of cell mediated immunity in experimental Chagas disease. Zeitschrift fur Parasitenkunde 52: 11-17, 1977.

19. Rowland EC, Kuhn RE. Suppression of cellular responses in mice during Trypanosoma cruzi infection. Infection and Immunity 20: 393-397. 1978.

20. Silva LHP, Nussenzweig V. Sobre uma cepa de Trypanosoma cruz $i$ altamente virulenta para o camundongo branco. Folia Clinica et Biologica 20: 191-207, 1953.

21. Teixeira ARL. Competência imunológica do paciente chagásico. Imunodepressão na forma aguda inaparente. Autoimunidade no hospedeiro imunizado. Tese de Doutorado. Universidade Federal de Minas Gerais. Belo Horizonte. 1981

22. Teixeira ARL, Teixeira G, Macedo J, Prata A. Acquired cell-mediated immunodepression in acute Chagas. disease. Journal of Clinical Investigation 62: 11321141,1978

23. Warren KS. Inhibition of granuloma formation around Schistosoma mansoni eggs. The American Journal of Pathology 56:293-303, 1969.

24. Warren KS, Domingo EO, Cowan RBT. Granuloma formation around schistosome eggs as a manifestation of delayed hypersensitivity. The American Journal of $\mathrm{Pa}-$ thology 51: 735-756. 1967. 